\title{
Parent-Child Collaboration Preventing Obesity and Acquiring a Healthy Lifestyle. A Review Study
}

\author{
Vasiliki Karavida \\ Eleni Tympa \\ Assistant Professor, Department of Early Years Learning and Care \\ University of Ioannina, Ioannina, Greece \\ George Panousis \\ Democritus University of Thrace \\ Faculty of Physical Education and Sport Science, Komotini, Greece
}

\begin{abstract}
Obesity during infancy and childhood is a threat for children's health and has reached alarming dimensions worldwide. This is one of the most common eating problems with short and long-term effects on both physical and psychological development of the children. Childhood is a critical stage in human life, as developing eating habits lay the foundation for the child's future eating preferences. It is therefore necessary to seek effective interventions to prevent and address the phenomenon. Worldwide Intervention programs aiming at the adoption of appropriate eating habits have been recorded. The data collection was done through the literature review with keywords. In all actions, it was emphasized the priority of the involvement of children's environment, especially children's family. Programs and interventions to prevent obesity aim at timely information as well as the increase of the children's physical activity and healthy eating.
\end{abstract}

Keywords: childhood, intervention, obesity, eating habits, healthy lifestyle, collaboration

\section{Introduction}

According to the World Health Organization childhood obesity is one of the most serious challenges in the field of public health of the $21^{\text {st }}$ century (Delisle et al., 2015). It has been recognized that aspects of the current nutritional environment contribute to childhood obesity, with the effects being evident in both close and extended environments. Given that a lot of children already develop obesity from preschool age, with parents playing an important role in their close environment, it is considered necessary to create early interventions (Larsen et al., 2015).

Early experiences in the children's life determine the course of their health and development. Increasing evidence indicates that obesity prevention should commence in early childhood because weight-related behaviors, such as food preferences and levels of physical activity begin during the early years (Svensson et al., 2016; Tandon et al., 2016). It is now admissible that environmental impacts include both activities and processes related to nutrition and the potential accumulation of activity and nutrition (Larsen et al., 2015). As a result, parents' eating habits and the availability of food in the house significantly influence the formation of a model healthy diet (Svensson et al., 2016).

Overweight and obesity have been interrelated with numerous medical conditions, including fatty liver disease, sleep apnea, type 2 diabetes, asthma, high cholesterol, cardiovascular disease, glucose intolerance, insulin resistance and orthopedic problems. As childhood is the cornerstone of preventing overweight, type 2 diabetes and cardiovascular diseases, lifestyle changes such as increased physical activity, reduced sedentary behavior and improved nutrition are considered vital (Viitasalo et al., 2016).

Dietary behavior of parents affects child's environment and their eating habits. Given that parents are responsible for building their children's environment, regarding 'when', 'what kind of' and 'how much' food is provided to them, children should be given the chance to determine the quantity they want to consume from this food. At the same time, the eating practices of parents in which food is used as a reward for controlling a child's behavior or emotions do not appear to be effective in establishing a healthy intake (Karavida et al, 2017; Larsen et al., 2015).

Consequently, parents can support children's participation in internal satiety patterns and at the same time control healthy eating habits. Only by avoiding 'junk' food and rewarding food, by setting clear-cut and healthy rules as to when and what to eat, as well as providing a variety of healthy foods with repeated exposure and rewarding the child when trying new and healthy food so as to stimulate prevention, will parents be able to minimize the risk of raising overweight and obese children (Holley, Haycraft, \& Farrow, 2015; Larsen et al., 2015). Increased physical activity of children is also important in the fight against obesity. 
At the same time, increased consumption of fruit and vegetables is necessary, something that does not depend solely on parents having been informed, but also on the availability of the specific foods at home (World Health Organization [WHO], 2012).

The development of effective programs for the prevention and intervention of childhood obesity is considered an essential step against the obesity epidemic (Skouteris et al., 2012). Children should be the target of obesity interventions worldwide, as their age range is more flexible and the risk factors for developing overweight and obesity are more easily modified, while without appropriate intervention obese children will face serious diseases in their later life (Pamungkas \& Chamroonsawasdi, 2019; Skouteris et al., 2012). Programs and interventions for the prevention of obesity, in addition to their implementation at an early age, are based mainly on the eating habits of parents, aiming at their timely information, the increased physical activity of the children as well as the consumption of fruit and vegetables (Holley et al., 2015; Larsen et al., 2015; Viitasalo et al., 2016).

Parents are a powerful factor in managing childhood obesity because they can manage behaviors interrelated with the child weight by discussing healthy eating habits and creating a healthy dietary environment. Interventions, based on a home environment, can improve parenting skills in terms of healthy eating habits, increase physical activity, prevent a sedentary lifestyle and promote a healthy lifestyle among the children (Danford, Schultz, \& Marvicsin, 2015; West et al., 2010). Due to the importance of the role of the family and especially of the parents, the interventions for the prevention of childhood obesity based on the involvement of the parents were considered appropriate to be studied.

The present work aims to study intervention programs that have implemented at home by parents to preschool children in order to prevent and treat childhood obesity, as well as to evaluate the effectiveness.

\section{Methods}

\subsection{Materials and Methods}

A systematic review of PubMed and Google Scholar databases was performed in order to conduct this study. Articles were searched on the internet using key words, including 'home-based interventions', 'childhood obesity', and 'parental involvement'. For the retrieved articles, the publication period was limited to eight years between 2012 and 2019. Exclusion criteria included studies that: (a) were not home-based or family-based interventions, (b) the children were over six years old, (c) related to children with health problems, (d) were published in reviews and post-reviews without including interventions for the prevention and treatment of childhood obesity, (e) were not published in English. The selected articles have the following characteristics:

- All interventions involved children of early childhood from birth to six years of age.

- All studies have been conducted in developed and developing countries

- The interventions concern the eating habits and the level of physical activity of the children.

\section{Results}

Details of the nutrition programs, the sample, the aim and the design of the five studies are given in Table_1.

Table_1. Details of the intervention nutritional programs

\begin{tabular}{|c|c|c|c|}
\hline Program & Main aim & Sample & Design \\
\hline $\begin{array}{l}\text { "Eat Healthy, Stay Active!" } \\
\text { Herman, Nelson, Teutsch \& } \\
\text { Chung } \\
2012 \\
\text { Pennsylvania, Texas, } \\
\text { Arizona, Rhode Island and } \\
\text { New York }\end{array}$ & $\begin{array}{l}\text { To examine the effectiveness of the } \\
\text { "Eat Healthy, Stay Active!" pilot } \\
\text { program, a multisite, 6-month } \\
\text { educational intervention to promote } \\
\text { healthy nutrition and physical } \\
\text { activity among Head Start staff, } \\
\text { parents and children. } \\
\text { The goal was to increase knowledge } \\
\text { and awareness of important factors } \\
\text { in obesity and chronic disease } \\
\text { prevention among Head Start staff, } \\
\text { parents and children and to assist in } \\
\text { translating those skills into action. }\end{array}$ & $\begin{array}{l}\text { Sample age: } \\
\text { Preschool children } \\
\text { Sample size: } \\
112 \text { children, } 438 \\
\text { parents and } 496 \text { staff }\end{array}$ & $\begin{array}{l}\text { Pre-post questionnaires and anthropometric measurements examined } \\
\text { changes in body mass index (BMI), knowledge and behaviors related to } \\
\text { nutrition and physical activity. The children's curriculum included } \\
\text { appropriate activities that helped children learn the food groups and the } \\
\text { importance of healthy eating and exercise. } \\
\text { All preschool children were exposed to a minimum of one activity per } \\
\text { day. During this same period, all parents were exposed to a minimum of } \\
\text { six hours of activities. The three common core elements of the } \\
\text { intervention included: } \\
\text { - Staying healthy: diabetes awareness and obesity prevention } \\
\text { - Nutrition education and physical activity } \\
\text { - Healthy eating and smart shopping on a budget }\end{array}$ \\
\hline $\begin{array}{l}\text { "LAUNCH" (Learning about } \\
\text { Activity and Understanding } \\
\text { Nutrition for Child Health) } \\
\text { Stark, Filigno, Bolling, } \\
\text { Ratcliff, Kichler, Robson et } \\
\text { al. } \\
2014 \\
\text { Cincinnati, Ohio }\end{array}$ & $\begin{array}{l}\text { To produce small decreases or } \\
\text { stabilize the rate of child weight } \\
\text { gain }\end{array}$ & $\begin{array}{l}\text { Sample age: } \\
\text { Children aged } 2-5.5 \\
\text { years } \\
\text { Sample size: } \\
42 \text { families }\end{array}$ & $\begin{array}{l}\text { Phase I (Intensive Intervention), } 12 \text { weekly sessions, alternating between } \\
\text { group-based clinic sessions (parent and child concurrent groups) and } \\
\text { individual home visits targeted lifestyle behavior modification and } \\
\text { improving parenting skills and } \\
\text { Phase II (Maintenance), } 12 \text { weeks of every-other-week sessions, } \\
\text { alternating between group clinic and individual home sessions focused } \\
\text { on helping families maintain treatment gains by engaging parents in } \\
\text { long-term planning, problem-solving around individual barriers, and use } \\
\text { of parenting skills to promote maintenance of diet and activity changes }\end{array}$ \\
\hline
\end{tabular}




\begin{tabular}{|c|c|c|c|}
\hline $\begin{array}{l}\text { "MINISTOP" (Mobile-based } \\
\text { Intervention Intended to Stop } \\
\text { Obesity in Preschoolers) } \\
\text { Delishe, Sandin, Forsum, } \\
\text { Henriksson, Trolle-Lagerros, } \\
\text { Larsson et al. } \\
2015 \\
\text { Sweden (county of } \\
\text { Östergötland) }\end{array}$ & $\begin{array}{l}\text { To determine the effectiveness of a } \\
\text { parental intervention on body } \\
\text { fatness, dietary habits, physical } \\
\text { fitness, physical activity and } \\
\text { sedentary behavior in preschool } \\
\text { children. }\end{array}$ & $\begin{array}{l}\text { Sample age: } \\
\text { 4-year-old } \\
\text { Sample size: } \\
300 \text { children and } \\
\text { their parents }\end{array}$ & $\begin{array}{l}\text { The six interventions consist of a web-based application to help parents } \\
\text { promote healthy eating and physical activity in children. MINISTOP is } \\
\text { based on the Social Cognitive Theory and involves the delivery of a } \\
\text { comprehensive, personalized program of information and text messages } \\
\text { based on existing guidelines for a healthy diet and active lifestyle in } \\
\text { preschool children. }\end{array}$ \\
\hline $\begin{array}{l}\text { "HomeStyles" } \\
\text { Byrd-Bredbenner, Martin- } \\
\text { Biggers, Koenings, Quick, } \\
\text { Hongu \& Worobey } \\
2017 \\
\text { New Jersey and Arizona }\end{array}$ & $\begin{array}{l}\text { To help parents of young children } \\
\text { shape or makeover (i.e., change) } \\
\text { their home environment and } \\
\text { lifestyles to promote optimal child } \\
\text { growth and development, and } \\
\text { childhood obesity. }\end{array}$ & $\begin{array}{l}\text { Sample age: } \\
\text { Children aged 2-5 } \\
\text { years and their } \\
\text { parents } \\
\text { Sample size: } \\
300 \text { parents }\end{array}$ & $\begin{array}{l}\text { HomeStyles has two delivery modes: } \\
\text { - independent online learning, and } \\
\text { - in-home, face-to-face, individualized learning facilitated by trained } \\
\text { home visitation staff. }\end{array}$ \\
\hline $\begin{array}{l}\text { "GFHS" (Guelpf Family } \\
\text { Health Study) } \\
\text { Krystia, } \\
\text { Darlington, Ma, Buchorose, } \\
\text { Haines } \\
2019 \\
\text { Ontario, Canada }\end{array}$ & $\begin{array}{l}\text { To explore the effect of a home- } \\
\text { base childhood obesity-prevention } \\
\text { intervention on parental body } \\
\text { composition, acknowledging the } \\
\text { important role of addressing the } \\
\text { whole family when implementing } \\
\text { childhood obesity preventions. }\end{array}$ & $\begin{array}{l}\text { Sample age: } \\
\text { Children aged } 1.5-5 \\
\text { years } \\
\text { Sample size: } \\
44 \text { families }\end{array}$ & $\begin{array}{l}\text { The intervention included home visits and emails for a period of six } \\
\text { months. Body composition, height and weight were also recorded. }\end{array}$ \\
\hline
\end{tabular}

All the intervention programs we studied concerned preschool children (1.5-5 years) and their parents. Three of the studies were conducted in the USA, one in Canada and one in Sweden. Four of the studies aimed at promoting a healthy lifestyle within the family, as well as increasing physical activity. One study (GFHS-Guelpf Family Health Study) aimed at reducing the body weight of the parents and through it the weight of the children.

In its six-month implementation, there was a significant reduction in the body weight and obesity of those participating in the 'Eat Healthy, Stay Active!' program (children and adults). Moreover, participants showed statistically significant improvements in knowledge and behavior in the field of nutrition and health. An increase was observed in both frequency and duration of exercise in almost all participants.

The 'LAUNCH' program also showed a reduction in children's Body Mass Index, which supports its effectiveness in reducing obesity in a small sample of the population.

The effectiveness of the 'MINISTOP' implementation was discussed by Parekh et al. (2018), who noted higher fruit and vegetable consumption and lower unhealthy snack consumption, but no changes related to children's physical activity were observed.

With the implementation of the "HomeStyles" program, Byrd-Bredbenner et al. (2018), found that the participated families improved their dietary behaviors and practices that protect against childhood obesity. The provision of savory and fatty snacks decreased whereas physical activity increased.

The results of the intervention program "GFHS" indicated significantly lower body mass and a smaller waist circumference of the parents at six months and a lower BMI at 18 months.

\section{Discussion}

The current bibliography review describes five intervention programs designed to help families with young children, aged 0-5, form a family environment and lifestyle suitable for the optimal development of children and prevent the onset of childhood obesity, employing strategies that could become part of their daily routine. Three of the programs also used modern technology in order to inform and guide parents.

The findings of the programs show that the interventions which are implemented at an early stage can be effective in managing children's weight and can be the basis for the prevention of childhood obesity. Also, they can prove dietary behaviors in the family. Parents play an important role in building the child's early nutritional environment, as their own eating habits and practices influence the child's developing eating preferences and habits and consequently his energy intake throughout his life (Bassul, Corish, \& Kearney, 2020).

The involvement and cooperation of parents, especially of preschool children, with the school is the key factor in acquiring healthy living habits not only to prevent obesity but also to bring a change in the lifestyle of both the child and the family. Intervention programs such as the "FUSION" have shown to affect both food preparation habits and the consuming and eating habits of the whole family (Tympa et al., 2019).

Another important factor in maintaining healthy eating habits is the self-regulation and socialization of the child. Parents who are supportive of their child's self-regulation and initiative taking, both at a personal and a social level, do a better job guiding their children in acquiring healthy eating habits. Recent studies have shown that two-yearold children with good self-regulation and emotional balance were less likely to develop obesity two years later (Graziano, Calkins, \& Keane, 2010)

Maternal response is also considered to be essential in optimal infant development, as well as the ability for selfregulation, learning and attachment (Feldman, Greenbaum, \&Yirmiya, 1999; Milgrom, Westley, \& Gemmill, 
2004). The timely response of the mother, especially throughout the first years of the child's life, helps the child to acquire self-control and actively and willingly comply with the rules of a healthy diet.

\section{Conclusions}

Clearly, food and physical activity are the core elements of the daily interactions of parents and preschool children. The collaboration of parent-child that respects autonomy, freedom and proper information, will offer children greater willingness to learn and acquire new healthy habits. The collaboration of the parents-child-school trinity is an even more important criterion in establishing healthy choices and good practices. The better these three parts work together, the more successfully the child's full development is achieved.

Overweight and obesity are significantly associated with the family lifestyle, especially when this is unhealthy. It is therefore necessary to implement intervention programs for both parents and children in order to promote a healthy lifestyle (Paduano et al., 2020).

Of course, future research is needed to determine the value and effectiveness of such interventions when implemented in larger population groups.

\section{References}

Bassul, C., Corish, A. C., \& Kearney, M. J. (2020). Associations between the Home Environment, Feeding Practices and Children's Intakes of Fruit, Vegetables and Confectionary/Sugar-Sweetened Beverages. International Journal of Environment Research and Public Health, 17(13), 4837. doi: 10.3390/ijerph17134837

Byrd-Bredbenner, C., Martin-Biggers, J., Povis, G. A., Worobey, J., Hongu, N., \& Quick, V. (2018). Promoting healthy home environments and lifestyles in families with preschool children: HomeStyles, a randomized controlled trial. Contemporary Clinical Trials, 64, 139-151. doi: 10.1016/j.cct.2017.10.012

Danford, C. A., Schultz, C., \& Marvicsin, D. (2015). Parental roles in the development of obesity in children: challenges and opportunities. Research and Reports in Biology, 6, 39-53. doi: 10.2147/rrb.s75369

Delisle, C., Sandin, S., Forsum, E., Henriksson, H., Trolle-Lagerros, Y., Larsson, C., Maddison, R., Ortega, B. F., Ruiz, R. J., Silfvernagel, K., Timpka, T., \& Löf, M. (2015). A web- and mobile phone-based intervention to prevent obesity in 4-year-olds (MINISTOP): A population-based randomized controlled trial. $B M C$ Public Health, 15, 95. doi: 10.1186/s12889-015-1444-8

Feldman, R., Greenbaum, C. W., \& Yirmiya, N. (1999). Mother-infant affect synchrony as an antecedent of the emergence of self-control. Developmental Psychology, 35(1), 223-231. doi: 10.1037/0012-1649.35.1.223

Graziano, P. A., Calkins, S. D., \& Keane, S. P. (2010). Toddler self-regulation skills predict risk for pediatric obesity. International Journal of Obesity, 34(4), 633-641. doi: 10.1038/ijo.2009.288

Holley, C. E., Haycraft, E., \& Farrow, C. (2015). "Why don’t you try it again?” A comparison of parent led, home based interventions aimed at increasing children's consumption of a disliked vegetable. Appetite, 87, 21522. doi: 10.1016/j.appet.2014.12.216

Karavida, V., Pesxos, D., Vrionis, G., \& Euaggelou, A. (2017). The role of eating habits in childhood obesity. Archives of Hellenic Medicine, 34(1), 27-31.

Larsen, J. K., Hermans, R. C. J., Sleddens, E. F. C., Engels, R. C. M. E., Fisher, J. O., \& Kremers, S. S. P. J. (2015). How parental dietary behavior and food parenting practices affect children's dietary behavior. Interacting sources of influence? Appetite, 89, 246-57. doi: 10.1016/j.appet.2015.02.012

Milgrom, J., Westley, D. T., Gemmill, A. W. (2004). The mediating role of maternal responsiveness in some longer term effects of postnatal depression on infant development. Infant Behavior and Development, 27(4), 443454. doi: 10.1016/j.infbeh.2004.03.003

Paduano, S., Borsari, L., Salvia, C., Arletti, S., Tripodi, A., Pinca, J., \& Borella, P. (2020). Risk Factors for Overweight and Obesity in Children Attending the First Year of Primary Schools in Modena, Italy. Journal of Community Health, 45(2), 301-309. doi: 10.1007/s10900-019-00741-7

Pamungkas, R. A., \& Chamroonsawasdi, K. (2019). Home-based interventions to treat and prevent childhood obesity: A systematic review and meta-analysis. Behavioral Sciences, 9(4), 38. doi: 10.3390/bs9040038

Parekh, N., Henriksson, P., Delisle Nyström, C., Silfvernagel, K., Ruiz, J. R., Ortega, F. B., Pomeroy, J., \& Löf, M. (2018). Associations of Parental Self-Efficacy With Diet, Physical Activity, Body Composition, and Cardiorespiratory Fitness in Swedish Preschoolers: Results From the MINISTOP Trial. Health Education and Behavior, 45(2), 238-246. doi: 10.1177/1090198117714019

Skouteris, H., McCabe, M., Ricciardelli, L. A., Milgrom, J., Baur, L. A., Aksan, N., \& Dell'Aquila, D. (2012). Parent-child interactions and obesity prevention: a systematic review of the literature. Early Child Development and Care, 182(2), 153-174. doi: 10.1080/03004430.2010.548606 
Svensson, V., Sobko, T., Ek, A., Forssén, M., Ekbom, K., Johansson, E., Nowicka, P., Westertahl, M., Riserus, U., \& Marcus, C. (2016). Obesogenic dietary intake in families with 1-year-old infants at high and low obesity risk based on parental weight status: baseline data from a longitudinal intervention (Early STOPP). European Journal of Nutrition, 55, 781-792. doi: 10.1007/s00394-015-0899-9

Tandon, P. S., Tovar, A., Jayasuriya, A. T., Welker, E., Schober, D. J., Copeland, K., Dev, A. D., Murriel, A. L., Amso, D., \& Ward, D. S. (2016). The relationship between physical activity and diet and young children's cognitive development: A systematic review. Preventive Medicine Reports, 3, 379-90. doi: 10.1016/j.pmedr.2016.04.003

Tympa, E., Karavida, V., Paschali, T., \& Psyrropoulos, Z. (2019). The "Cr-EAT-Ive Schools Feasibility Study": Aiming to Reduce Food Waste by Implementing Relevant Actions including the Completion of Food Waste Diaries by Kindergarten Families. Journal of Education \& Social Policy, 6(4), 80-85. doi:10.30845/jesp.v6n4p11

Viitasalo, A., Eloranta, A. M., Lintu, N., Väistö, J., Venäläinen, T., Kiiskinen, S., Karjalainen, P., Peltola, J., Lampinen, E. K., Haapala, E. A., Paananen, J., Schwab, U., Lindi, V., \& Lakka, T. A. (2016). The effects of a 2-year individualized and family-based lifestyle intervention on physical activity, sedentary behavior and diet in children. Preventive Medicine, 87, 81-88. doi: 10.1016/j.ypmed.2016.02.027

West, F., Sanders, M. R., Cleghorn, G. J., \& Davies, P. S. W. (2010). Randomised clinical trial of a family-based lifestyle intervention for childhood obesity involving parents as the exclusive agents of change. Behaviour Research and Therapy, 48(12), 1170-1179. doi: 10.1016/j.brat.2010.08.008

World Health Organization. (2012). Prioritizing areas for action in the field of population-based prevention of Childhood Obesity. World Health Organization. Available at: https://apps.who.int/iris/bitstream/handle/10665/80147/9789241503273_eng.pdf;jsessionid=CE8690C45F E9333C594A98C504E8F412?sequence=1 